\title{
Diets of Antarctic sponges: links between the pelagic microbial loop and benthic metazoan food web
}

\author{
Andrew R. Thurber* \\ Moss Landing Marine Laboratories, 8272 Moss Landing Road, Moss Landing, California 95039, USA \\ Present address: Integrative Oceanography Division, Scripps Institution of Oceanography, 9500 Gilman Drive, \\ San Diego, California 92093-0208, USA
}

\begin{abstract}
Antarctic benthic suspension feeders may consume water column bacteria to buffer the seasonal variation of primary production, yet little is known about consumption of ultraplankton by this fauna. In the present study 3 experiments - fatty acid analysis, stable isotope concentrations, and laboratory-based feeding - addressed the nutritional role of the microbial loop in 4 species of Antarctic sponge: Homaxinella balfourensis, Isodictya setifera, Kirkpatrickia variolosa, and Sphaerotylus antarcticus. Sponges were sampled at distances between 115 and $840 \mathrm{~m}$ from the McMurdo Station sewage outfall to investigate local food source variability. The sewage effluent acted as a tracer for particulates larger than bacteria and was identified isotopically and by the biomarker 18:2(n-6). Sponge diets differed between each species: I. setifera consumed mostly bacteria, as indicated by the ratio of bacterial fatty acids to polyunsaturated fatty acids; $H$. balfourensis consumed larger particles, indicated by an abundance of 22:6(n-3) and an outfall signature; $K$. variolosa was intermediate between these two, with abundant 22:6(n-3), but an isotopic signature similar to I. setifera. The diet of $S$. antarcticus was not completely resolved; fatty acid analysis supported its similarity to $K$. variolosa, yet the isotopic analysis separated it from the other sponges, suggesting that symbionts were abundant enough to confound the results. This study provides the first application of fatty acid analysis to determine diet composition of sponges, the first species-specific stable isotopic analysis of Antarctic sponges, and the first conclusive evidence of differential utilization of microbial loop components by co-occurring sponges.
\end{abstract}

KEY WORDS: Bentho-pelagic coupling $\cdot$ Fatty acid analysis $\cdot$ Sponge diet $\cdot$ Antarctica $\cdot$ Stable isotope Delta(13)C $\cdot \operatorname{Delta}(15) \mathrm{N} \cdot$ Porifera

\section{INTRODUCTION}

A seminal discovery over the last $30 \mathrm{yr}$ has been the unexpected importance of bacteria in oceanic carbon flow (Azam et al. 1983). However, the bulk of research has focused on the pelagic ecosystem, where microbial carbon is transferred through protozoan grazers (Smetacek et al. 1990, Sherr \& Sherr 1994). More recently, studies have addressed the role of pelagic bacteria in the diet of benthic organisms (Gili et al. 2001, Orejas et al. 2001, Pile 2005). The ability of benthic organisms to directly consume bacteria could be a crucial step in energy transfer where bacteria are a relatively abundant source of food, including deep-sea, tropical, and polar ecosystems. The Southern Ocean where protozoa, dissolved organic material (DOM) and bacteria play key roles for larger fauna (Smetacek et al. 1990), is an area in which an understanding of this bentho-bacteriopelagic coupling is critical to understanding ecosystem function. This study used biomarkers and a feeding experiment to address the diet of sponges in the high Antarctic, where an ability to feed on water column bacteria could provide a link between the pelagic microbial loop and the benthic metazoan food web.

Sponges in the Antarctic provide habitat and food to a variety of organisms, yet their sources of food have not been completely identified, limiting our knowl- 
edge of the benthic food web. In McMurdo Sound, one of the few high-Antarctic ecosystems, $>64^{\circ} \mathrm{S}$, in which food webs have been studied, a wide variety of animals feed on the sponge fauna, including the asteroids Odontaster meridionalis, O. validus, Perknaster fuscus antarcticus, and Acodontaster conspicuous, and the nudibranch Doris kerguelenensis (Dayton et al. 1974, Wagele 1989). Sponges are uniquely capable of filtering down to the bacterial size range, between 0.2 and $2 \mu \mathrm{m}$ (Reiswig 1971, Pile et al. 1997, Gili et al. 2001), but only one study has examined the feeding ecology of Antarctic sponges. Kowalke (2000) determined that Isodictya kerguelensis and Mycale accerata are able to retain particles $>0.4$ and $0.6 \mu \mathrm{m}$, respectively. In all of these studies, regardless of location, particle retention size was used to address diet. However, these studies represent only the 'potential' diet of an organism, since they do not differentiate between whether the carbon is simply retained or consumed and utilized.

To address a 'realized' diet, techniques such as stable isotope and fatty acid analyses (FAA) provide a time-integrated measure of the carbon source utilized and assimilated by an organism. Stable isotope analysis takes advantage of predictable fractionation, or discrimination, of carbon and nitrogen isotopes by primary producers during fixation. This creates a unique signature depending on the type of fixation and isotopic availability (reviewed in Michener \& Schell 1994). As the carbon and nitrogen move up the food web, this signature is conserved, $+1 \pm 1 \%$ for carbon and $+3 \pm 1 \%$ for nitrogen each time it is consumed. By knowing the relative abundance of ${ }^{13} \mathrm{C}$ to ${ }^{12} \mathrm{C}$ and ${ }^{15} \mathrm{~N}$ to ${ }^{14} \mathrm{~N}$ in the organism, the relative trophic level and diet overlap of the organism can be determined (Michener \& Schell 1994). This technique has been employed in the Antarctic for several years (Wada et al. 1987, Dunton 2001, Nyssen et al. 2002); however, the studies that have analyzed sponge tissue have neither identified the species nor removed lipids (Kaehler et al. 2000, Dunton 2001, Nyssen et al. 2002), limiting the application of their findings. The lipid carbon isotopic composition of a consumer does not reflect its trophic position; a heterotroph's lipids are a combination of those derived from its diet or those which have undergone a large carbon isotopic fractionation step during synthesis (Deniro \& Epstein 1977).

FAAs allow for independent assessment of food sources, which may avoid some of the traditional pitfalls of stable isotope application (Gannes et al. 1997). Most organisms can only synthesize a subset of the types of fatty acids (FAs) that they require. Those FAs that they cannot synthesize are directly incorporated from their food sources, termed dietary FAs, and even many of those that they can synthesize, or de novo FAs, are still incorporated from their diet. Different primary producers synthesize specific FAs, which can then be identified as dietary FAs in their consumers (Table 1); the specific FAs of note in the Antarctic are 22:6(n-3), synthesized by flagellates, ciliates, and most phytoplankton, and 20:5(n-3), synthesized mainly by diatoms, although it is also present to a lesser degree in other taxa (Zhukova \& Kharlamenko 1999, Dalsgaard et al. 2003). When material is recycled through most shallow-water bacteria, polyunsaturated fatty acids (PUFAs) are not conserved, and the PUFA signature is replaced; bacteria also have a unique suite of FAs, consisting of 15:0, 17:0, isoand anteiso-FAs (Zhukova \& Kharlamenko 1999, Dalsgaard et al. 2003). By analyzing FA constituents, the relative input of bacteria, diatoms, and flagellates/ ciliates to the diet of sponges can be determined.

This paper presents the stable isotopic and FA composition of 4 species of high-Antarctic sponges, coupled with a bacterial feeding experiment to identify their diet. For greater resolution in diet identification, sampling was carried out within the pollution gradient of the McMurdo Station sewage outfall. The pollution gradient consists of macerated human waste discharged into the ocean with human fecal matter spreading down-current after the initial deposition of larger particles. Sewage has a unique isotopic composition (Van Dover et al. 1992, Conlan et al. 2006) and FA content, identified in this study by 18:2(n-6) (Rieley et al. 1997). This pollution gradient perturbs the food available in the water column with regards to certain size classes of particles, and so by tracing its perturbation in the diet of the animals, it increases

Table 1. Common fatty acid (FA) biomarkers used to identify food sources within the marine environment

\begin{tabular}{|c|c|}
\hline Source & Biomarker \\
\hline Phytoplankton & Polyunsaturated fatty acids (PUFA ${ }^{\mathrm{a}}$ ) \\
\hline Diatoms & $16: 1(n-7)^{a}, 20: 5(n-3)^{a}, 16: 4(n-1)^{b}$ \\
\hline $\begin{array}{l}\text { Prymnesiophytes } \\
\text { (Phaeocystis sp.) }\end{array}$ & $16: 1(n-7)^{a}, 18: 0^{a}, 18: 1(n-9)^{a}, 18: 4(n-3)^{a}$ \\
\hline Dinoflagellates & $22: 6(n-3)^{a},(n-3)$ PUFAs \\
\hline $\begin{array}{l}\text { Heterotrophic } \\
\text { nanoflagellates, ciliates }\end{array}$ & $22: 6(n-3)^{c}$ \\
\hline Bacteria & $15: 0^{c}, 17: 0^{c}$, iso and anteiso $F A s^{c}$, no PUFAs ${ }^{a, d}$ \\
\hline Sewage/terrestrial & $18: 2(n-6)^{e}$ \\
\hline \multicolumn{2}{|c|}{$\begin{array}{l}\text { a Dalsgaard et al. (2003), 'b Viso \& Marty (1993), ' Zhukova \& Kharlamenko } \\
\text { (1999), d but see Nichols (2003), e Rieley et al. (1997) }\end{array}$} \\
\hline
\end{tabular}


the resolution of the dietary analysis. This allowed me to test if the microbial loop is a utilized source of food by Antarctic sponges, while also determining if sponge species exhibit niche separation through diet partitioning.

\section{MATERIALS AND METHODS}

Water sampling. Water sampling was carried out to identify whether the water column microbial abundance was impacted by the sewage outfall. This was addressed by measuring: (1) FA composition of particulate matter, (2) abundance of water column, freeliving bacteria, and (3) abundance of total coliform bacteria. Water was collected at the indicated sampling locations and at the sewage outfall (Fig. 1). All sampling was done using a 10 l Niskin bottle on 5 consecutive days from 17 November to 22 November 2002. All stations were sampled at approximately $2 \mathrm{~m}$ above the bottom, and sampling coincided with the deployment of an S4 current meter (Ocean Systems) to indicate prevailing currents during sampling.
FA composition of the particulate matter was determined by filtering between 6 and $10 \mathrm{l}$ of the water through a pre-combusted Whatman glass fiber filter (GF/F) with a nominal pore size of $0.6 \mu \mathrm{m}$. Water was filtered until the GF/F would not pass any more water. The filters were frozen at $-80^{\circ} \mathrm{C}$ as soon as filtration was finished. One location was sampled per day, and each location was sampled only once.

Microbial abundance was measured using the 4',6diamidino-2-phenylindole (DAPI) techniques of Sherr et al. (2001). After preservation with $2.5 \%$ gluteraldehyde, samples were filtered within $48 \mathrm{~h}$. Ten milliliters of sample were vacuum filtered onto $0.2 \mu \mathrm{m}$ pore sized nucleopore membrane filters. After mounting on slides, the membrane filters were frozen and shipped to Moss Landing Marine Laboratories for epifluorescence enumeration. Influence of the outfall on bacterial abundance was analyzed using regression analysis, with distance from the outfall being the independent factor and bacterial abundance the dependent factor. Fecal coliform abundance was measured using mColiblue 24 protocols (Millipore).

Tissue sampling and analysis. Sponge tissue collection for FA and stable isotope analysis was carried out
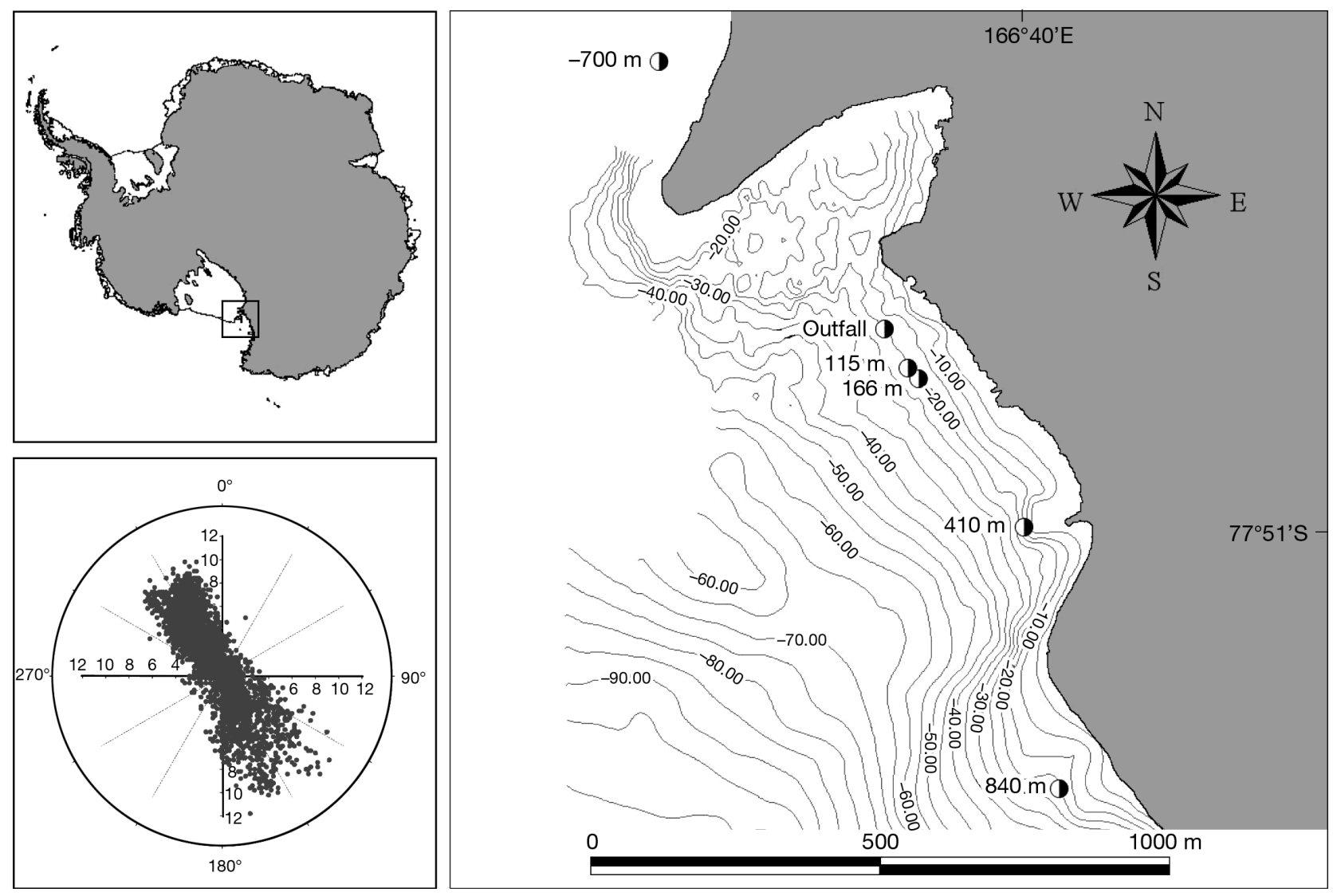

Fig. 1. Locations of sponge and water collections (including distances from sewage outfall) at McMurdo Station, Antarctica. Current speed $\left(\mathrm{cm} \mathrm{s}^{-1}\right)$ and direction during the time of water collection are shown in the vector diagram as recorded by an S4 current meter 
from 5 to 23 November 2002 at McMurdo Station, Antarctica (Fig. 1). Along the fecal pollution gradient, 4 stations at distances of 115, 166, 410, and $840 \mathrm{~m}$ south of the outfall and 1 location $700 \mathrm{~m}$ north (referred to as $-700 \mathrm{~m}$ from here on) were sampled. All collections were made at $20 \mathrm{~m}$ depth using SCUBA. Sponges of the species Homaxinella balfourensis, Isodictya setifera, Kirkpatrickia variolosa, and Sphaerotylus antarcticus were collected at each location. These species were chosen due to their abundance throughout the sampling area, their diverse morphology, and, in the case of $H$. balfourensis, its previously documented episodic population explosions, at times approaching $80 \%$ cover of the seafloor within the study location (Dayton 1989). At the 115, 166, and $-700 \mathrm{~m}$ stations, all samples were collected within a $3 \mathrm{~m}$ radius. At the $410 \mathrm{~m}$ site, a $10 \times 3 \mathrm{~m}$ area perpendicular to the outfall was sampled due to low abundances of all sponge species. At the $840 \mathrm{~m}$ site, a $20 \times 20 \mathrm{~m}$ transect was used because the sponges were patchily distributed. All specimens of a given species within the described area were sampled, but only a haphazard selection of the total collected were analyzed.

During sponge tissue collection, a small portion of the osculum was removed with a pair of scissors and placed in a mesh bag. In the laboratory, the sponges were sorted by species and placed in $0.6 \mu \mathrm{m}$ filtered seawater for $24 \mathrm{~h}$ to remove the ambient seawater from the tissue. Then they were placed into individual bags and frozen at $-20^{\circ} \mathrm{C}$ until analysis. FAA was carried out by Ellen Dickstein at the Bacterial Identification and Fatty Acid Analysis Laboratory, University of Florida, with the Sherlock system (MIDI systems), using approximately $0.5 \mathrm{~g}$ of tissue. The method used was modified from Technical Note No. 101 available from MIDI systems. In brief, lipids were saponified using a sodium hydroxide, methanol, and water solution; they were heated to $100^{\circ} \mathrm{C}$ and then rapidly cooled. FA methyl esters were produced by adding hydrochloric acid and methanol prior to extraction using a 1:1 mixture of hexane and methyl tert-butyl ether. The samples were analyzed on an Agilent gas chromatograph with a flame ionization detector and a $25 \times 0.2 \mathrm{~mm}$ ultra 2 column. Stable isotope analyses were carried out at the Stable Isotope Laboratory, University of California, Davis, after lipid removal and drying at Moss Landing Marine Laboratories. Acidification was not necessary since no calcium carbonate was present. Stable isotopic results are presented in $\delta$ notation in reference to the Pee Dee Belemnite standard for $\delta^{13} \mathrm{C}$ and to atmospheric nitrogen for $\delta^{15} \mathrm{~N}$ using the standard equation (Wada et al. 1987).

Regression analyses were conducted on the arcsine square-root transformed FA proportion data to analyze differences within species between sites, and a nested analysis of variance (ANOVA) with Tukey post hoc test was used to compare the species. The ratio of bacterial FA (specifically 15:0, 17:0, and all branched FAs) to PUFA (all polyunsaturated fatty acids) was normalized using an arcsine quadratic-root divided by 100 transformation. Stable isotopic results were analyzed using the same statistical tests, except $\delta^{13} \mathrm{C}$ required no transformation and $\delta^{15} \mathrm{~N}$ required square-root transformation to achieve normality. Statistical comparisons were carried out using Systat v. 10 (SPSS). A principal component analysis (PCA) to address the overall trends of FA composition was run on the entire data set of FAs as well as fatty alcohols. The purpose of the PCA was to include all of the FAs present rather than those that had been identified a priori as biomarkers. Furthermore, it identifies which FAs drive the patterns that account for the most variability within the samples. The PCA was run using Primer v. 5.2.3 (Primer-E) on $\log _{10}$ transformed data.

Feeding experiments. Feeding experiments were conducted in the laboratory to demonstrate that the sponges were removing bacteria from the water column rather than incorporating symbiotic bacterial biomass. Each of the sponge species was collected using SCUBA between 28 November and 7 December 2004, at either the southern $840 \mathrm{~m}$ site (Replicates 1, 2, and 3) or the northern $-700 \mathrm{~m}$ site (Replicates 4 and 5). Sponges were placed individually in 7.51 buckets after being removed from the substratum when necessary, or placed in the bucket with the substratum still attached when possible. After transport back to Crary Laboratory Aquarium at McMurdo Station, sponges were acclimated for $>24 \mathrm{~h}$ with a flow-through seawater system in a water table to keep them at $<2{ }^{\circ} \mathrm{C}$. No epibionts were removed, nor was the water aerated to prevent disturbing the sponges by additional handling, or bubbles impacting the sponges. A control consisted of an empty bucket placed in the seawater table at the same time with the same flow-through regime. At the start of the experiment, the water flow was shut off and $15 \mathrm{ml}$ of the water samples were taken initially, then at half hour intervals for $2 \mathrm{~h}$. These water samples were preserved with a $0.2 \mu \mathrm{m}$ filtered, $10 \%$ buffered formaldehyde solution. They were stained with DAPI, and $15 \mathrm{ml}$ were filtered onto $0.22 \mu \mathrm{m}$ poretics membrane filters (Osmonics) and enumerated using epifluorescent microscopy. Although Sherr et al. (2001) recommend filtration within $24 \mathrm{~h}$, this was not possible due to field supply limitations. Therefore, samples were stored for 2 mo before filtration at Moss Landing Marine Laboratories. To enumerate the low abundances of bacteria in certain samples, an $81 \mu \mathrm{m}$ wide transect was run on the filter until 200 bacteria were counted, at which point the length of the transect was recorded. This method generated reproducible 
results with low concentrations of bacteria, and very similar results to the method suggested by Sherr et al. (2001) when the abundances approximated normal seawater. All feeding experiment conclusions specifically address visible nucleoid bacteria, as their abundance was constant regardless of time preserved (Vosjan \& van Noort 1998).

Sponge species removal of bacteria was compared by integrating under a standardized (count divided by initial abundance) curve of bacteria $\mathrm{ml}^{-1}$ and using a 1-way ANOVA with a Tukey post hoc test for multiple comparison analysis.

\section{RESULTS}

\section{Water column}

The water column sampling indicated that the majority of particles produced by the sewage outfall were larger than bacteria. Proximity to the outfall did not significantly impact the DAPI-enumerated abundance of bacteria in the water column $\left(\mathrm{p}=0.49, \mathrm{r}^{2}=\right.$ 0.03 ; Table 2). These direct counts of bacterial abundance yielded values between $3.1 \times 10^{4}$ and $4.1 \times 10^{4}$ bacteria $\mathrm{ml}^{-1}$. These values did not increase in samples that had a positive result for fecal bacteria. The abundance of the fecal coliform bacteria varied from 0 to 54 colonies per $100 \mathrm{ml}$ present at the outfall, and coliforms were found throughout the study area, including both the $-700 \mathrm{~m}$ and $840 \mathrm{~m}$ sites, though in much lower abundances. The FA sewage indicator, 18:2(n-6), was found in the water column at the $-700,0$, and $166 \mathrm{~m}$ locations (Table 2). Because the FA samples were collected at the same time that fecal coliform bacteria were present, the FA sewage pollution indicator represented the sewage plume in this ecosystem and was retained on a GF/F. Although this suggests that the outfall had an impact on the microbial or larger community, the abundance of fecal bacteria was 5 orders of magnitude less than the abundance of naturally occurring bacteria (Table 2). The sewage signature was insignificant in the microbial size range, but was noticeable in the total FAs present on the GF/F, meaning they were still an available component of food, but the size class that contained the signature was larger than bacteria. The occurrence of the fecal indicators at the $-700 \mathrm{~m}$ location (normally upcurrent from the outfall) is explained by an oscillating flow parallel to the shore as recorded by the current meter (Fig. 1). It is important to note that the only PUFAs present were 18:2(n-6) and 18:3(n-6), with the former indicative of a terrestrial/sewage signature. Neither 20:5(n-3), nor 22:6(n-3), 2 FAs common to phytoplankton, were present, espousing the importance of consuming non-phytoplankton-sized organisms throughout the year in the Antarctic.

\section{Tissue fatty acids}

The FA composition of the sponges indicated the species had different diets; one example of this was the differential incorporation of the sewage signature. The fatty acids that decreased with distance from the outfall were 18:2(n-6) and 18:1(n-9) (Fig. 2, Table 3). 18:2 (n-6), a terrestrial/sewage biomarker, was most abun- 

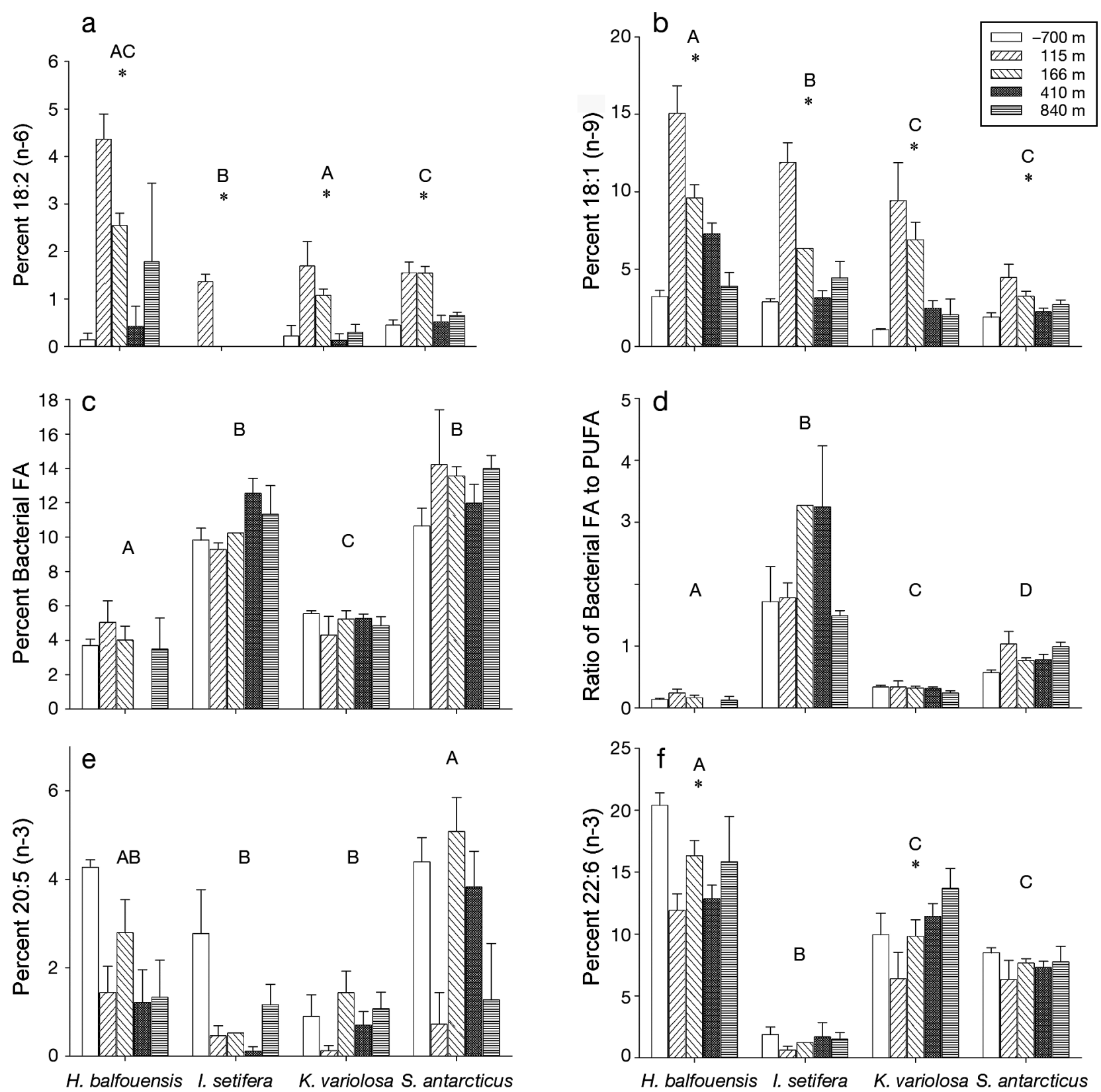

Fig. 2. Homaxinella balfourensis, Isodictya setifera, Kirkpatrickia variolosa, and Sphaerotylus antarcticus. Percent composition ( $\pm 1 \mathrm{SE}$ ) of (a) 18:2(n-6), (b) 18:1(n-9), (c) bacterial fatty acids (FAs) (15:0, 17:0, iso- and antiso-FA), (d) ratio of bacterial FAs to polyunsaturated FAs (PUFA), (e) 20:5(n-3), and (f) 22:6(n-3) in 4 species of sponge at varying distances from the McMurdo Station outfall. Locations presented from N to S. Location $166 \mathrm{~m}$ for I. setifera had no replication, and the lack of error bars reflects this. Differences among species are indicated by different letters over the species, and a significant change with distance is indicated by an asterisk. Letters do not compare data from different graphs within the figure. Statistical results presented in Table 3

dant in Homaxinella balfourensis and least abundant in Isodictya setifera, in which it was present only at the station nearest the outfall, and was never $>5 \%$ of the FA composition. 18:1(n-9), a ubiquitous FA indicative of degradation processes, also decreased in all species with distance from the outfall, and was most abundant in $H$. balfourensis.
The importance of bacteria as a food source differed among the sponge species as well. Bacterial FA concentrations were highest in Isodictya setifera and Sphaerotylus antarcticus, composing $>9 \%$ of their total FAs (Fig. 2, Table 3). The input of bacterial FA to I. setifera was 2 to 3 times greater than that of PUFAs (Fig. 2), which are normally lost through bacterial cy- 
Table 3. Homaxinella balfourensis, Isodictya setifera, Kirkpatrickia variolosa, and Sphaerotylus antarcticus. Statistical comparison between a selection of fatty acid (FA) biomarker concentrations. Nested ANOVAs compare between species, and linear regressions indicate differences in concentration with increasing distance from the McMurdo Station sewage outfall. Post hoc results indicated in Fig. 2. PUFA: polyunsaturated fatty acid

\begin{tabular}{|c|c|c|c|c|c|c|}
\hline \multirow[t]{2}{*}{ FA } & \multicolumn{2}{|c|}{ Nested ANOVA } & \multirow[b]{2}{*}{ Species } & \multicolumn{3}{|c|}{ Regression analysis } \\
\hline & Species & Station (species) & & $\begin{array}{c}\text { Coefficient } \\
\left(\% \mathrm{~m}^{-1} \times 10^{-4}\right)\end{array}$ & $\mathrm{p}$ & $\mathrm{R}^{2}$ \\
\hline $18: 2(n-6)$ & $F_{3,69}=13.9 \mathrm{p}<0.01$ & $F_{15,69}=15.5 \mathrm{p}<0.01$ & $\begin{array}{l}\text { H. balfourensis } \\
\text { I. setifera } \\
\text { K. variolosa } \\
\text { S. antarcticus }\end{array}$ & $\begin{array}{l}-2.542 \\
-1.544 \\
-1.158 \\
-0.775\end{array}$ & $\begin{array}{l}<0.01 \\
<0.01 \\
<0.01 \\
<0.01\end{array}$ & $\begin{array}{l}0.66 \\
0.68 \\
0.31 \\
0.35\end{array}$ \\
\hline $18: 1(n-9)$ & $F_{3,69}=25.7 p<0.01$ & $F_{15,69}=12.9 \mathrm{p}=0.01$ & $\begin{array}{l}\text { H. balfourensis } \\
\text { I. setifera } \\
\text { K. variolosa } \\
\text { S. antarcticus }\end{array}$ & $\begin{array}{r}-2.395 \\
-2.062 \\
-2.415 \\
0.601\end{array}$ & $\begin{array}{l}<0.01 \\
<0.01 \\
<0.01 \\
<0.01\end{array}$ & $\begin{array}{l}0.69 \\
0.48 \\
0.50 \\
0.28\end{array}$ \\
\hline Bacterial FA & $F_{3,69}=99.2 \mathrm{p}<0.01$ & $F_{15,69}=5.37 \mathrm{p}<0.01$ & $\begin{array}{l}\text { H. balfourensis } \\
\text { I. setifera } \\
\text { K. variolosa } \\
\text { S. antarcticus }\end{array}$ & $\begin{array}{r}-0.947 \\
0.195 \\
0.313 \\
-0.277\end{array}$ & $\begin{array}{l}0.18 \\
0.55 \\
0.44 \\
0.40\end{array}$ & $\begin{array}{l}0.08 \\
0.02 \\
0.03 \\
0.04\end{array}$ \\
\hline $\begin{array}{l}\text { Bacterial FA } \\
\text { to PUFA ratio }\end{array}$ & $F_{3,69}=85.6 \mathrm{p}=0.01$ & $F_{15,69}=5.5 \mathrm{p}<0.01$ & $\begin{array}{l}\text { H. balfourensis } \\
\text { I. setifera } \\
\text { K. variolosa } \\
\text { S. antarcticus }\end{array}$ & $\begin{array}{r}-27.415 \\
-11.841 \\
4.307 \\
-3.114\end{array}$ & $\begin{array}{l}0.19 \\
0.44 \\
0.02 \\
0.03\end{array}$ & $\begin{array}{l}0.07 \\
0.04 \\
0.26 \\
0.22\end{array}$ \\
\hline $20: 5(n-3)$ & $F_{3,69}=5.8 \mathrm{p}<0.01$ & $F_{15,69}=3.5 p<0.01$ & $\begin{array}{l}H . \text { balfourensis } \\
\text { I. setifera } \\
\text { K. variolosa } \\
\text { S. antarcticus }\end{array}$ & $\begin{array}{r}0.224 \\
1.158 \\
0.455 \\
-0.517\end{array}$ & $\begin{array}{l}0.74 \\
0.07 \\
0.34 \\
0.50\end{array}$ & $\begin{array}{l}0.10 \\
0.19 \\
0.05 \\
0.02\end{array}$ \\
\hline $22: 6(n-3)$ & $F_{3,69}=109.9 \mathrm{p}<0.01$ & $F_{15,69}=2.4 \mathrm{p}=0.01$ & $\begin{array}{l}\text { H. balfourensis } \\
\text { I. setifera } \\
\text { K. variolosa } \\
\text { S. antarcticus }\end{array}$ & $\begin{array}{l}1.224 \\
0.761 \\
1.310 \\
0.304\end{array}$ & $\begin{array}{r}<0.01 \\
0.24 \\
0.03 \\
0.23\end{array}$ & $\begin{array}{l}0.34 \\
0.08 \\
0.23 \\
0.07\end{array}$ \\
\hline
\end{tabular}

cling. The bacterial FA:PUFA ratios for all species were significantly different from each other, with the lowest ratios in Homaxinella balfourensis (Table 3, Fig. 2).

The algal biomarkers were distinct in the different species of sponge as well. The diatom biomarker 20:5(n-3) was present in all species, but another indicative diatom FA, 16:4(n-3), was completely absent, suggesting that diatoms were not a major source of nutrition (Fig. 2). Abundance of the flagellate biomarker 22:6(n-3) was species specific, but was most abundant in species with the lowest concentration of bacterial markers (Fig. 2). Homaxinella balfourensis had the highest abundance of 22:6(n-3), indicating consumption of flagellates and larger particles, whereas Isodictya setifera had the lowest abundance of 22:6(n-3), suggesting $I$. setifera consume primarily bacteria. For further information about the FAs present see supplementary material at www.int-res.com/articles/suppl/ m351p077_app.pdf.

Two axes of the PCA accounted for $60 \%$ of the variance while identifying that the greatest variability in FA concentration was between species rather than

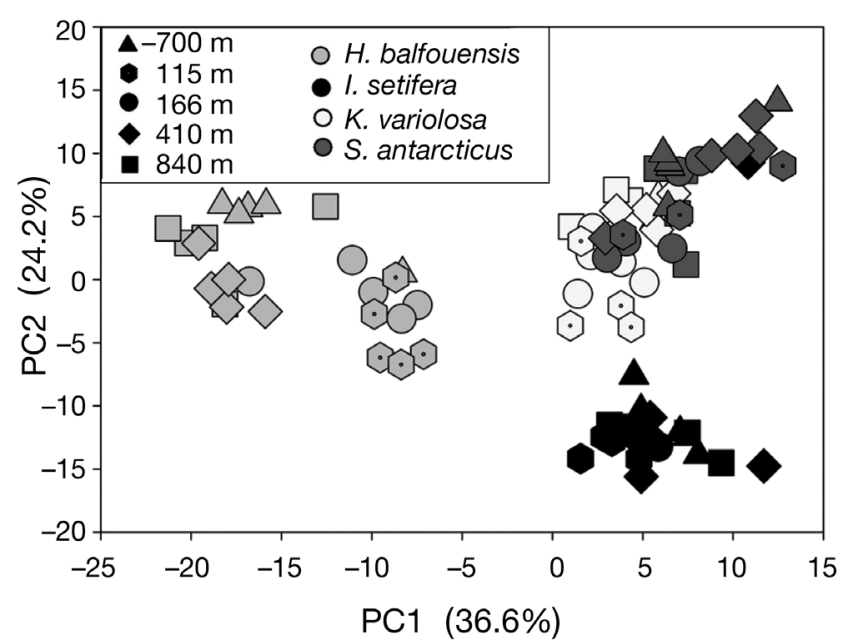

Fig. 3. Homaxinella balfourensis, Isodictya setifera, Kirkpatrickia variolosa, and Sphaerotylus antarcticus. PC1 and PC2 of a principal component analysis of the fatty acid constituents of 4 species of sponge at varying distances from the McMurdo Station sewage outfall. Shapes signify station distance; shading signifies sponge species 
between sites (Fig. 3). Homaxinella balfourensis and Isodictya setifera were the most distinct of the species analyzed in terms of their diets, with the greatest overlap in diets between Kirkpatrickia variolosa and Sphaerotylus antarcticus. 22:6(n-3), the flagellate PUFA (a large component of PC1 and PC2), was largely responsible for separating $H$. balfourensis from the other species (Fig. 4). 16:1(n-7), a common FA within bacteria (and a component of PC2), separated $I$. setifera from $S$. antarcticus and $K$. variolosa. Two additional FAs that were clear factors in the PCA were cyclo 17:0, a common FA within bacteria, and the saturated FA 30:0, the source of which is unknown (Fig. 4). Only 1 of the $I$. setifera samples did not group with the rest of its species, and instead grouped with $S$. antarcticus. These results indicate that certain a priori selected and discussed dietary biomarkers were a major component in differentiating the species.

\section{Stable isotopes}

As was observed in the FAA, there was: (1) little overlap in the stable isotopic composition of the different species and (2) differential incorporation of the outfall signature, suggesting a unique diet for each species (Fig. 5). The 2 species that did have overlapping values were Kirkpatrickia variolosa and Isodictya setifera $\left(p>0.05\right.$ for both $\delta^{15} \mathrm{~N}$ and $\left.\delta^{13} \mathrm{C}\right)$; the other 2 species were different from each other as well as from $K$. variolosa and $I$. setifera (Table 4). All of the species, except I. setifera, incorporated sewage-derived material, as was illustrated by a significant shift in their carbon isotopic value with increased distance from the outfall (regression analysis, Table 4). The $166 \mathrm{~m}$ location was the most impacted by the outfall in 3 of the 4 species, while the $115 \mathrm{~m}$ site was in all cases the second most impacted. The relative proximity of these stations to the outfall in comparison to the other sites and the large SE of the replicates from the $166 \mathrm{~m}$ site may explain this pattern; nonetheless, distance to outfall was significant for 3 of the 4 species. The overlap in isotopic composition but differential utilization of sewage between $K$. variolosa and $I$. setifera, as indicated by a carbon isotopic shift in $K$. variolosa only, suggests they utilize a similar source of carbon, but that $K$. variolosa consumes larger particles (such as those derived from the sewage outfall).

\section{Feeding experiment}

The feeding study supported differences in bacterial consumption between the species and concluded that Isodictya setifera was able to filter bacteria out of the water column (Fig. 6, $F_{4,20}=5.180, \mathrm{p}<0.01$ ). I. setifera was the only species to significantly decrease the abundance of bacteria in comparison to the control. Kirkpatrickia variolosa, although not significantly dif-

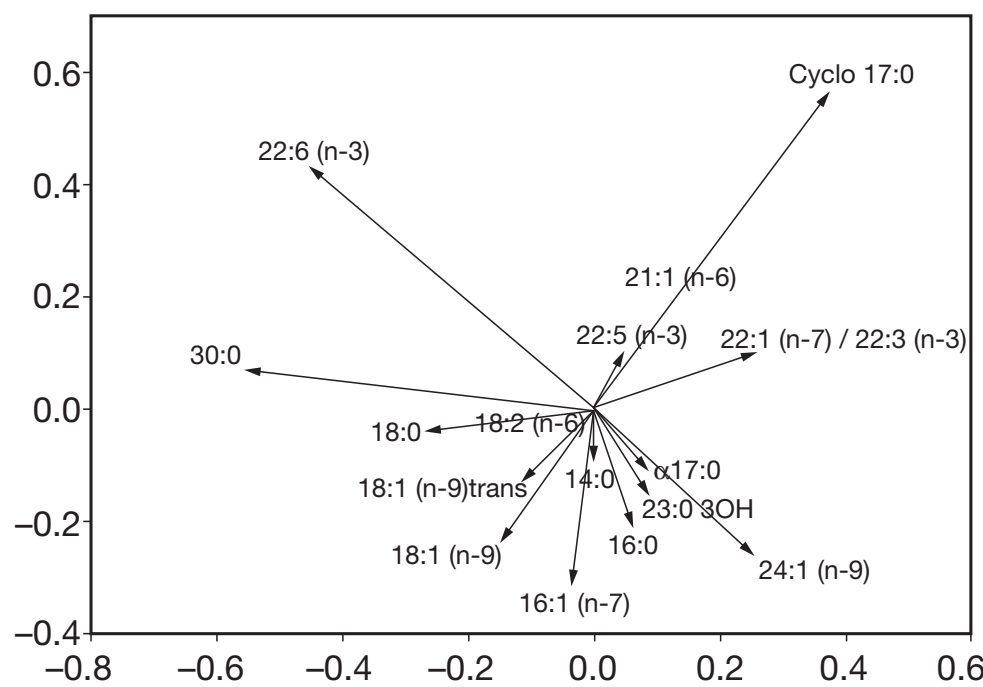

Fig. 4. Bi-plot of the eigenvectors that accounted for $>10 \%$ of the variability in PC1 and PC2

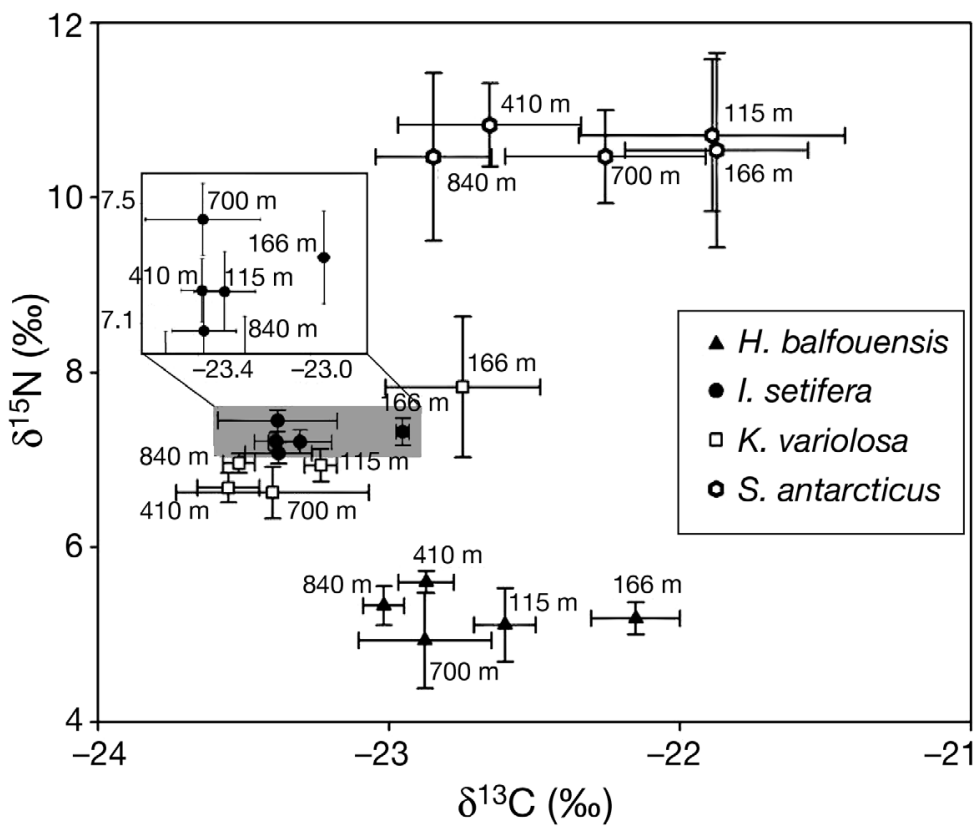

Fig. 5. Homaxinella balfourensis, Isodictya setifera, Kirkpatrickia variolosa, and Sphaerotylus antarcticus. Stable isotopic concentration ( $\pm 1 \mathrm{SE})$ of 4 species of sponge at indicated distances from the McMurdo Station sewage outfall, Antarctica. Boxed section with I. setifera data is expanded for clarity 
Table 4. Homaxinella balfourensis, Isodictya setifera, Kirkpatrickia variolosa, and Sphaerotylus antarcticus. Statistical comparison between the stable isotopic concentrations. Nested ANOVAs compare between species, and linear regressions indicate differences in concentration with increasing distance from the McMurdo Station sewage outfall

\begin{tabular}{|c|c|c|c|c|c|c|}
\hline \multirow[t]{2}{*}{ Isotope } & \multicolumn{2}{|c|}{ Nested ANOVA } & \multirow[b]{2}{*}{ Species } & \multicolumn{2}{|c|}{ Regression analysis } & \multirow[b]{2}{*}{$\mathrm{R}^{2}$} \\
\hline & Species & Station (species) & & $\begin{array}{c}\text { Coefficient } \\
\left(\% \mathrm{~m}^{-1} \times 10^{-4}\right)\end{array}$ & $\mathrm{p}$ & \\
\hline$\delta^{15} \mathrm{~N}$ & $\begin{array}{l}F_{3,67}=89.0 \mathrm{p}<0.01 \\
\text { Post hoc results: } \\
\text { H.b. } \neq \text { S.a. } \neq \\
\text { I.s. }=\text { K.v. }\end{array}$ & $F_{16,67}=0.38 \mathrm{p}=0.98$ & $\begin{array}{l}\text { H. balfourensis } \\
\text { I. setifera } \\
\text { K. variolosa } \\
\text { S. antarcticus }\end{array}$ & $\begin{array}{r}0.217 \\
-0.128 \\
-1.408 \\
-0.283\end{array}$ & $\begin{array}{l}0.84 \\
0.75 \\
0.33 \\
0.89\end{array}$ & $\begin{array}{l}0.00 \\
0.00 \\
0.05 \\
0.00\end{array}$ \\
\hline$\delta^{13} \mathrm{C}$ & $\begin{array}{l}F_{3,67}=24.9 \mathrm{p}<0.01 \\
\text { Post hoc results: } \\
\text { H.b. } \neq \text { S.a. } \neq \\
\text { I.s. }=\text { K.v. }\end{array}$ & $F_{16,67}=2.72 \mathrm{p}<0.01$ & $\begin{array}{l}\text { H. balfourensis } \\
\text { I. setifera } \\
\text { K. variolosa } \\
\text { S. antarcticus }\end{array}$ & $\begin{array}{r}-8.219 \\
-2.837 \\
-7.748 \\
-11.657\end{array}$ & $\begin{array}{r}<0.01 \\
0.16 \\
0.02 \\
0.04\end{array}$ & $\begin{array}{l}0.40 \\
0.10 \\
0.21 \\
0.20\end{array}$ \\
\hline
\end{tabular}

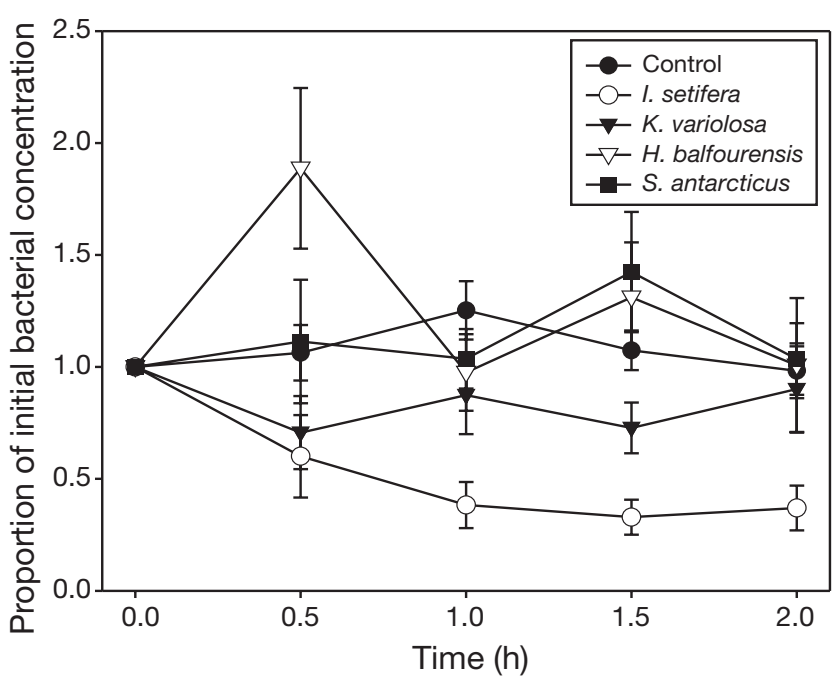

Fig. 6. Homaxinella balfourensis, Isodictya setifera, Kirkpatrickia variolosa, and Sphaerotylus antarcticus. Proportion ( $\pm 1 \mathrm{SE})$ decrease of total bacterial abundance over time in a closed system containing the indicated species of sponge or a control of no sponge $(\mathrm{n}=5)$. Post hoc results indicate that $I$. setifera was different from the control, $H$. balfourensis and $S$. antarcticus; $H$. balfourensis and $S$. antarcticus were not different from each other or the control; and $K$. variolosa was not significantly different from any of the treatments

ferent from the control, was also not significantly different from $I$. setifera, supporting an intermediate impact on bacterial abundance. The majority of bacteria were consumed within the first half hour of the experiment in 4 of the $5 \mathrm{I}$. setifera trials, and after $1 \mathrm{~h}$ the bacterial concentrations had decreased from $2 \times$ $10^{4}$ to $<10^{3}$ cells $\mathrm{ml}^{-1}$. There was a large amount of variability within Sphaerotylus antarcticus and Homaxinella balfourensis, but neither of them consistently decreased the abundance of bacteria. These results are conclusive in that $I$. setifera is able to consume water column bacteria.

\section{DISCUSSION}

\section{Food sources and size classes of FAs}

The dominant taxa of plankton within different size classes have indicative FAs; this makes is possible to identify by FAA which size classes are eaten by a consumer. Picoplankton between 0.2 and $2 \mu \mathrm{m}$ are dominated by bacteria, and thus, consumption is indicated by a high proportion of branched and odd numbered FAs as well as a lack of PUFAs. Nanoplankton, between 2 and $20 \mu \mathrm{m}$ and dominated by heterotrophic nanoflagellates and some phytoplankton, are where 22:6(n-3) starts to become abundant, yet this FA is prevalent throughout the microplankton and is thus only indicative of particles $>2 \mu \mathrm{m}$. Diatoms are some of the largest phytoplankton, and their indicative FAs include 20:5(n-3) and 16:4(n-1), yet these FAs are not conclusive evidence of consumption of diatoms since they are present, albeit in low abundances, in many phytoplankton groups. In the case that an animal consumes across a variety of size classes, it will have a distribution of the FAs indicative of each group.

Certain FAs are ubiquitous and pose problems when interpreting which size class they represent; one in particular is $16: 1(n-7)$, which the PCA indicated to be one of the FAs that discriminated between the species. Although in many cases it indicates diatoms, it is also known to be abundant in bacteria (Dalsgaard et al. 2003) and to represent as much as 5 to $10 \%$ of the FAs within Phaeocystis (Nichols et al. 1991), seasonally one of the dominant sources of production in the area of this study (Stoecher et al. 1995). Phaeocystis in the food web can be identified by a high abundance of 18:1(n9), between 7 and $11 \%$, and a very high proportion of 14:0, between 30 and $48 \%$ (Nichols et al. 1991). In all of the sponges studied here, $<5.5 \%$ of their FAs were 
14:0, with the majority much lower than this. Phaeocystis has also been identified by the presence of 18:4(n-3) and 18:5(n-3) (Hamm et al. 2001), neither of which were present in the sponges here. As such, Phaeocystis was neither the source of the 16:1(n-7), nor an abundant component of the sponges' diet.

The other possible source of 16:1(n-7) is diatoms, and, while most diatoms are too large for sponges to consume, their presence in the sponge tissues is plausible. Most sponges can retain, with high grazing efficiency, particles up to $10 \mu \mathrm{m}$ (Pile et al. 1996, Turon et al. 1997), with particle retention size reaching $50 \mu \mathrm{m}$, which could include smaller diatoms. In addition, diatoms are known to live within the tissues of sponges, including tissues of Homaxinella balfourensis (Bavestrello et al. 2000), which could still explain the abundance of 20:5(n-3) and 16:1(n-7). However, this is inconclusive, as diatoms are not the sole source of 20:5(n-3) and there was no evidence of 16:4(n-1), another diatom biomarker (Dalsgaard et al. 2003).

\section{Diet tracers in sponges}

These data represent the first stable isotopic values for high-Antarctic $\left(>64^{\circ} \mathrm{S}\right)$ sponges and the only species-specific values for Antarctic sponges. Carbon and nitrogen isotope values obtained in this study had the same range as sponges from King George Island (Nyssen et al. 2002). Palmer Station sponges had $\delta^{13} \mathrm{C}$ values of $-27 \%$, considerably lower than any of the results here, even though the $\delta^{15} \mathrm{~N}$ values were similar (Dunton 2001). Kaehler et al. (2000) analyzed 2 nonspecified species of sponge and found no difference in $\delta^{13} \mathrm{C}$, but they did vary in $\delta^{15} \mathrm{~N}$, by approximately $2 \%$. In contrast to these previous studies, the sponges analyzed in the present study had their lipids removed and species were identified.

The FA composition of Antarctic sponges has not been previously reported, nor has the technique been applied for dietary purposes to populations elsewhere in the world. FAA has been applied to sponges for purposes of analyzing biosynthetic pathways (Carlalleira \& Pagan 2001), chemotaxonomy (Lawson et al. 1986), and for indicating transfer of symbiotic biomass into sponge cells (Hoffmann et al. 2005). In this regard, the current application of FA results to sponges is novel.

The application of stable isotopic analysis and FAA to sponges is an inexpensive way to analyze time-integrated diet, increasing our knowledge of the phylum. Due to logistical restraints, many habitats in which sponges thrive, such as the deep sea, do not lend themselves to thorough treatments in dietary analysis utilizing particle retention studies. The time required by such treatments has also restricted the number of spe- cies that have been analyzed. Because of this, the behavior of a few species of sponge has been extrapolated to an entire phylum of organisms. Analyses such as those presented here indicate how inappropriate these extrapolations are. The Antarctic is a location where this type of approach is critical, considering the $>300$ species of demosponges present, limited food resources that vary temporally, and the expense and logistical problems associated with laboratory work there.

\section{Dietary niche separation}

The sponge species all differed in their diet, exemplifying filter-feeder partitioning of food resources as 1 component of niche separation. Homaxinella balfourensis consumes mostly flagellates or larger particles, with only a small portion of its diet bacterially derived. Isodictya setifera consumes primarily bacteria, as indicated by the high ratio of bacterial FAs to PUFAs, the feeding experiment results, and a lack of outfall stable isotopic (SI) signature in its tissues. The stable isotopic results indicated that Kirkpatrickia variolosa has a diet similar to I. setifera, but with outfall influence, which supports a diet including larger particles. $K$. variolosa was differentiated from $I$. setifera partially by 22:6(n-3), the flagellate marker, compared to 16:1(n-7). In this particular case, it is likely that the $16: 1(n-7)$ is bacterially derived due to the high proportion of bacterial FAs within I. setifera. These results support $K$. variolosa's consumption of larger particles. Sphaerotylus antarcticus had the least conclusive results. The stable isotopic analysis indicated that $S$. antarcticus has a different source of nutrition than the other sponges. There was no change in the bacterial abundance during the feeding experiment, but abundant bacterial FAs. S. antarcticus's large shift in $\delta^{13} \mathrm{C}$ caused by distance to the outfall suggests they also feed on large particles. The diet of this species was not sufficiently resolved, possibly due to a symbiotic relationship with bacteria.

Niche separation in diet has not been previously shown for co-occurring sponges. While studies have shown different particle retention efficiencies between co-occurring species (Pile et al. 1997, Turon et al. 1997, Kowalke 2000, Pile 2005) and selectivity by sponges (Van De Vyver et al. 1990), they have not been able to confirm niche partitioning within the phyla due to ambiguity in what substantiates a different diet based on filtrate retention. This study is novel in showing that cooccurring sponges exhibit niche separation in their diet.

Niche separation due to resource partitioning has been studied in ecology for many years. The sponge fauna around the Antarctic is diverse and co-occurs with other filter-feeding taxa, e.g. octocorals, hydroids, tunicates, and bryozoans. These different taxa have 
distinct diets, yet commonly feed on particles larger than bacteria (Orejas et al. 2001). In the Antarctic, the co-occurrence of many different species with similar feeding strategies highlights the importance of niche partitioning through differential particle size utilization and specificity, as observed in this study.

\section{Feeding experiments}

The laboratory-based feeding results mirrored what was expected from the biomarker analyses. Stable isotopic analysis suggested that the 2 species with the most similar diet were Isodictya setifera and Kirkpatrickia variolosa, and these differed in their reliance on bacteria. In the laboratory, the only species that significantly decreased the number of bacteria in the water column was I. setifera; and $K$. variolosa was intermediate in its removal of bacteria between $I$. setifera and the control, exactly as would be expected from the isotopic results. Two of the assumptions inherent to this type of study are that the sponges are feeding and that they are not expelling ultraplankton (Pile et al. 1997), both of which would yield a negative result for bactivory, regardless of whether they consume bacteria. More conclusive results could be obtained by carrying out in situ particle retention studies that reduce the amount of handling stress on the sponges and by using flow cytometry, which would quantify removal of particles other than just bacteria, a limitation of the DAPI staining utilized here.

Although retention studies only provide an indication of potential diet for sponges, they are still necessary to interpret a biomarker approach. Sponges are hosts to a variety of symbionts; in fact, 3 of the 4 sponges here - excluding Isodictya setifera, which has not been studied in this regard - are known to have bacteria, archaea, dinoflagellates, and diatoms associated with them (Webster et al. 2004). FAA cannot inherently differentiate between symbionts and food sources. To do this, one must demonstrate the ability of the sponge to filter out the appropriate-sized particles that the biomarkers suggest it consumes. This presented problems in this study when addressing the diet of Sphaerotylus antarcticus. Since it had a high proportion of bacterial FAs present, one would conclude that it was bactivorous, yet it did not filter bacteria out of the water column in the feeding study. For the aforementioned reasons, this does not conclusively prove that they cannot filter bacteria, but it presents a possibility that symbionts are the source of its bacterial signature, and as such, the results are equivocal. This was not a problem for the other species studied, due to the agreement of the 3 techniques employed, although symbionts cannot be dismissed outright.

\section{Evolutionary and ecological implications}

Antarctic sponges are traditionally thought of as slow growing; Homaxinella balfourensis is the exception to this paradigm (Dayton 1989). The unique diet of $H$. balfourensis may help explain its faster growth rate. Population fluctuations of $H$. balfourensis in the McMurdo Sound area correlate with climatic oscillations (Dayton 1989). Population fluctuations were caused by increased anchor ice formation due to super-cooled water upwelling (Dayton 1989). This upwelled water could also impact food availability by exposing the sponges to deeper, older, more food-depleted water, similar to conditions on the west side of McMurdo Sound (Dayton \& Oliver 1977). Deeper water in the Antarctic has reduced bacterial abundance (Ducklow et al. 2001), and thus may have decreased abundance of bactivorous flagellates. During periods of upwelling, the limited abundance of larger food particles may hasten the population decline observed in $H$. balfourensis. Utilization of picoplankton may be an evolutionary advantage for long-lived sponge species, allowing them to compete with fast-growing species such as $H$. balfourensis.

The high Antarctic is typified by large seasonal variations in the abundance and size distribution of water column food present for filter feeders (Gili et al. 2001). Bacteria alone can account for up to $57 \%$ of the biomass of all living non-zooplankton (i.e. phytoplankton, bacteria, and ciliates) at the end of the summer (Becquevort et al. 2000), and in this study the water column had no FAs indicative of photosynthetic production (Table 2). Furthermore, the smaller size class, i.e. $<0.6 \mu \mathrm{m}$, which includes the majority of free-living pelagic bacteria, represents the largest proportion of the total carbon pool (Hobbie et al. 1977). Therefore, it is not surprising that certain species of sponges are not only adapted to feed on this size fraction of plankton, but appear to be specialists for it. These sponges can feed throughout the year, and they transfer the bacterial carbon to a plethora of animals that consume them, providing a buffer to the intense seasonality of the Antarctic ecosystem. This emphasizes the importance of the planktonic microbial community to the sponge fauna, as well as the greater Antarctic benthic ecosystem.

\section{CONCLUSIONS}

To conclude that sponges assimilate carbon from the microbial food web, one must demonstrate that bacteria can be captured by sponges and that these captured particles are consumed. The demonstration of particle capture has been the focus of sponge research for > 30 yr (see Reiswig 1971, Pile et al. 1996, 1997), but this study is the first to demonstrate that the retained 
bacteria are consumed by certain sponges. Although I dealt here with a model system in Antarctica, similar approaches could yield insight into the flow of carbon in ecosystems where bacterial production is high or where a limited food supply facilitates utilization of the pelagic microbial loop by the benthic ecosystem.

Acknowledgements. I thank S. L. Kim, K. Hammerstrom, J. L. Oliver, K. E. Conlan, A. Carlisle, D. Malone, J. Fisher, M. Donnellan, R. Sanders, and B. Zook for assisting with this research. S. L. Kim, R. Sanders, G. Cook, M. J. Forrest, R. L. Vega Thurber, L. A. Levin, C. R. Whitcraft, and 2 anonymous reviewers provided comments on this manuscript, and N. A. Welschmeyer graciously lent sampling equipment and laboratory space. I acknowledge the support of Raytheon Polar Services at McMurdo Station, especially R. Robbins, without which this work would not have been possible. This project was supported by the Earl and Ethyl Meyers Oceanographic Research Trust, the PADI Foundation, and the Dr. John H. Martin Memorial Scholarship awarded to A.R.T., and the National Science Foundation, Office of Polar Programs Grant 0126319 awarded to S. L. Kim.

\section{LITERATURE CITED}

Azam F, Fenchel T, Field JG, Gray JS, Meyer-Reil LA, Thingstad F (1983) The ecological role of water-column microbes in the sea. Mar Ecol Prog Ser 10:257-263

Bavestrello G, Arillo A, Calcinai B, Cattanea-Vietti R, Cerrano C, Gaino E, Penna A, Sara M (2000) Parasitic diatoms inside Antarctic sponges. Biol Bull (Woods Hole) 198:29-33

Becquevort S, Menon P, Lancelot C (2000) Differences of the protozoan biomass and grazing during spring and summer in the Indian sector of the southern ocean. Polar Biol 23: $309-320$

Carlalleira NM, Pagan M (2001) New methoxylated fatty acids from the Caribbean sponge Callyspongia fallax. J Nat Prod 64:620-623

Conlan KE, Rau GH, Kvitek RG (2006) $\delta^{13} \mathrm{C}$ and $\delta^{15} \mathrm{~N}$ shifts in benthic invertebrates exposed to sewage from McMurdo Station, Antarctica. Mar Pollut Bull 52:1695-1707

Dalsgaard J, St John M, Kattner G, Müller-Navarra D, Hagen W (2003) Fatty acid trophic markers in the pelagic marine environment. Adv Mar Biol 46:225-340

Dayton PK (1989) Interdecadal variation in an Antarctic sponge and its predators from oceanographic climate shifts. Science 243:1484-1486

Dayton PK, Oliver JS (1977) Antarctic soft-bottom benthos in oligotrophic and eutrophic environments. Science 197: 55-58

Dayton PK, Newman WA, Paine RT, Dayton LB (1974) Ecological accommodation in the benthic community at McMurdo Sound, Antarctica. Ecol Monogr 44:105-128

Deniro MJ, Epstein S (1977) Mechanisms of carbon isotope fractionation associated with lipid synthesis. Science 197: 261-263

Ducklow H, Carlson C, Church M, Kirckman D, Smith D, Steward G (2001) The seasonal development of the bacterioplankton bloom in the Ross Sea, Antarctica, 1994-1997. Deep-Sea Res Part II 48:4199-4221

Dunton KH (2001) $\delta^{15} \mathrm{~N}$ and $\delta^{13} \mathrm{C}$ measurements of Antarctic peninsula fauna: trophic relationships and assimilation of benthic seaweeds. Am Zool 41:99-112

Gannes LZ, O'Brien DM, Martinez del Rio C (1997) Stable iso- topes in animal ecology: assumptions, caveats, and a call for more laboratory experiments. Ecology 78:1271-1276

Gili J-M, Coma R, Orejas C, Lopez-Gonzalez PJ, Zabala M (2001) Are Antarctic suspension-feeding communities different from those elsewhere in the world? Polar Biol 24: $473-485$

Hamm C, Reigstad M, Riser CW, Mühlbach A, Wassmann P (2001) On the trophic fate of Phaeocystic pouchetii. VII. Sterols and fatty acids reveal sedimentation of $P$. pouchetii-derived organic matter via krill fecal strings. Mar Ecol Prog Ser 209:55-69

Hobbie JE, Daley RJ, Jasper S (1977) Use of nuclepore filters for counting bacteria by fluorescence microscopy. Appl Environ Microbiol 33:1225-1228

Hoffmann F, Larsen O, Thiel V, Rapp HT, Pape T, Michaelis W, Reitner J (2005) An anaerobic world in sponges. Geomicrobiol J 22:1-10

Kaehler S, Pakhomov EA, McQuaid CD (2000) Trophic structure of the marine food web at the Prince Edward Islands (Southern Ocean) determined by $\delta^{13} \mathrm{C}$ and $\delta^{15} \mathrm{~N}$ analysis. Mar Ecol Prog Ser 208:13-20

Kowalke J (2000) Ecology and energetics of two Antarctic sponges. J Exp Mar Biol Ecol 247:85-97

Lawson MP, Berquist PR, Cambie RC (1986) The cellular localization of long chain fatty acids in sponges. Tissue Cell 18: $19-26$

Michener RH, Schell DM (1994) Stable isotope ratios as tracers in marine aquatic food webs. In: Lajtha $\mathrm{K}$, Michener $\mathrm{RH}$ (eds) Stable isotopes in ecology and environmental science. Blackwell Scientific, Oxford, p 138-157

Nichols DS (2003) Prokaryotes and the input of polyunsaturated fatty acids to the marine food web. FEMS Microbiol Lett 219:1-7

Nichols PD, Skerratt JH, Davidson A, Burton H, McMeekin TA (1991) Lipids of cultured Phaeocystis pouchetii: signatures for food-web, biogeochemical and environmental studies in Antarctica and the Southern Ocean. Phytochemistry 30: 3209-3214

Nyssen F, Brey T, Lepoint G, Bouquegneau J, De Broyer C, Dauby P (2002) A stable isotope approach to the eastern Weddell Sea trophic web: focus on benthic amphipods. Polar Biol 25:280-287

Orejas C, Gili JM, Lopez-Gonzalez PJ, Arntz WE (2001) Feeding strategies and diet composition of four Antarctic cnidarian species. Polar Biol 24:620-627

Pile AJ (2005) Overlap in diet between co-occurring active suspension feeders on tropical and temperate reefs. Bull Mar Sci 76:743-749

Pile AJ, Patterson MR, Witman JD (1996) In situ grazing on plankton $<10 \mu \mathrm{m}$ by the boreal sponge Mycale lingua. Mar Ecol Prog Ser 141:95-102

Pile AJ, Patterson MR, Savarese M, Chernykh VI, Fialkov VA (1997) Trophic effects of sponge feeding within Lake Baikal's littoral zone. II. Sponge abundance, diet, feeding efficiency, and carbon flux. Limnol Oceanogr 42: 178-184

Reiswig HM (1971) Particle feeding in natural populations of three marine demosponges. Biol Bull (Woods Hole) 141: 568-591

Rieley G, Van Dover CL, Eglinton G (1997) Fatty acids as sensitive tracers of sewage sludge carbon in a deep-sea ecosystem. Environ Sci Technol 31:1018-1023

Sherr B, Sherr E (1994) Bactivory and herbivory: key roles of phagotrophic protists in pelagic food webs. Microb Ecol 28: 223-236

Sherr B, Sherr E, del Giorgio P (2001) Enumeration of total and highly active bacteria. In: Paul $\mathrm{J}$ (ed) Methods in 
microbiology, Vol 30. Marine microbiology. Academic Press, London, p 129-135

Smetacek V, Scharek R, Nothig EM (1990) Seasonal and regional variation in the pelagial and its relationship to the life history cycle of krill. In: Kerny R, Hempel G (eds) Antarctic ecosystems: ecological change and conservations. Springer, Berlin, p 103-114

Stoecher DK, Putt M, Moisan T (1995) Nano- and microplankton dynamics during the spring Phaeocystis sp. bloom in McMurdo Sound, Antarctica. Mar Biol Assoc UK 75:812-832

Turon X, Galera J, Uriz MJ (1997) Clearance rates and aquiferous systems in two sponges with contrasting life-history strategies. J Exp Zool 278:22-36

Van De Vyver GV, Vray B, Balaouane S, Toussanint D (1990) Efficiency and selectivity of microorganism retention by Ephydatia fluviatilis. In: Rutzler K (ed) New perspectives in sponge biology. Smithsonian Institute, Washington, DC, p 511-515

Van Dover CL, Grassle JF, Fry B, Garritt RH, Starczak VR (1992) Stable isotopic evidence for entry of sewage derived

Editorial responsibility: John C. Roff (Contributing Editor), Wolfville, Canada organic material into a deep-sea food web. Nature 360: 153-156

Viso AC, Marty JC (1993) Fatty-acids from 28 marine microalgae. Photochemistry 34:1521-1533

Vosjan JH, van Noort GJ (1998) Enumerating nucleoid-visible marine bacterioplankton: bacterial abundance determined after storage of formalin fixed samples agrees with isopropanol rinsing method. Aquat Microb Ecol 14: 149-154

Wada E, Terazaki M, Kabaya Y, Nemoto T (1987) ${ }^{15} \mathrm{~N}$ and ${ }^{13} \mathrm{C}$ abundance in the Antarctic ocean with emphasis on the biogeochemical structure of the food web. Deep-Sea Res 34: 829-841

Wagele H (1989) Diet of some Antarctic nudibranchs, Gastropoda, Opisthobranchia, Nudibranchia. Mar Biol 100: 439-441

Webster NS, Negri AP, Munro MMHG, Battershill CN (2004) Diverse microbial communities inhabit Antarctic sponges. Environ Microbiol 6:288-300

Zhukova NV, Kharlamenko VL (1999) Sources of essential fatty acids in the marine microbial loop. Aquat Microb Ecol 17: $153-157$

Submitted: September 27, 2006; Accepted: June 22, 2007 Proofs received from author(s): November 1, 2007 